Article

\title{
Multi-Factor Diagnostic and Recommendation System for Boron in Neutral and Acidic Soils
}

\author{
Richardly Lenz Clove Dupré, Lotfi Khiari * (D), Jacques Gallichand and Claude Alla Joseph \\ Département des Sols et Génie Agroalimentaire, Université Laval, Québec, QC G1K7P4, Canada \\ * Correspondence: lotfi.khiari@fsaa.ulaval.ca; Tel.: +418-656-2131
}

Received: 19 June 2019; Accepted: 22 July 2019; Published: 25 July 2019

check for updates

\begin{abstract}
Despite its inconveniences, the most recognized method to extract boron from soils is that of hot water extraction $\left(\mathrm{B}_{\mathrm{HW}}\right)$, which is used for diagnostics and recommendations. However, the Mehlich-3 (M3) method is widely used to extract and diagnose several elements at once $(\mathrm{P}, \mathrm{K}, \mathrm{Ca}$, $\mathrm{Mg}, \mathrm{Al}, \mathrm{B}, \mathrm{Cu}, \mathrm{Zn}, \mathrm{Fe}$, and $\mathrm{Mn}$ ) and is well adapted to routine analyses. The objective of our study was to develop a soil diagnostic and recommendation system for boron as a function of measured $B_{M 3}$ (and other interacting elements), crop type, and spreading methods. This system is based on three databases from either the international literature or the chemical characterization of acidic-to-neutral soils typical from Québec (Canada). The first database came from the characterization of 365 samples typical of Québec soils; it has been used to predict, by the AutoML (Automatic Machine Learnig) supervised learning algorithm, $\mathrm{B}_{\mathrm{M} 3}$ as a function of a set of parameters from the following: $\mathrm{B}_{\mathrm{HW}}$, $\mathrm{pH}_{\mathrm{W}}$, organic carbon $(\mathrm{OC}), \mathrm{Ca}_{\mathrm{M} 3}, \mathrm{~K}_{\mathrm{M} 3}$, and $\mathrm{Mg}_{\mathrm{M} 3}$. Depending on the parameters used, the $R^{2}$ between the measured and observed $\mathrm{B}_{\mathrm{M} 3}$ varied from 0.36 to 0.99 . This database allowed us to define two classifications for soil boron diagnostics and fertility evaluation. The Cate-Nelson analysis for these two models allowed us to define three boron fertility classes: Low, medium and high; that is $0.00-0.23,0.23-0.58$, and $0.58-3.70 \mathrm{mg} \mathrm{B} \mathrm{kg}^{-1}$, respectively, for $\mathrm{B}_{\mathrm{HW}}$, and 0.00-0.65, 0.65-1.03, and $1.03-12.70 \mathrm{mg} \mathrm{B} \mathrm{kg}^{-1}$, respectively, for $\mathrm{B}_{\mathrm{M} 3}$. The third database was extracted from 130 yield responses to increasing levels of boron; it was used to define a recommendation model for boron, based on AutoML, as a function of $\mathrm{B}_{\mathrm{M} 3}, \mathrm{pH}_{\mathrm{W}}$, the crop boron requirement (medium, high), and the type of spreading (broadcast, sidedress, foliar spraying). This model resulted in an $R^{2}$ of 0.63 .
\end{abstract}

Keywords: Boron fertilization; soil boron diagnostic; hot water boron; Mehlich 3 boron; supervised learning

\section{Introduction}

Fertile soils allow for root development and provide for the plant extraction of water and nutrients [1]. It is therefore important to evaluate agricultural soil potential using analytical tests for soil diagnostics. Despite the fact that the extraction of trace elements by plants is low, these elements are limiting for crop yields [2]. The characterizing and dosing of trace elements depend on analytical artefacts, since a change in process or a low contamination may greatly affect results [3]. In Québec, fertilization grids were mainly developed for major nutrients [4]. Soil chemical fertility diagnostics for most nutrients $(\mathrm{P}, \mathrm{K}, \mathrm{Ca}, \mathrm{Mg}, \mathrm{Cu}, \mathrm{Zn}$ and $\mathrm{Mn}$ ) are done after a Mehlich-3 solution extraction. However, some trace elements, such as boron, are not on this list since there are no calibrations with yield. For boron, most calibrations with crop yield are based on hot water extraction ( $\left.\mathrm{B}_{\mathrm{HW}}\right)$. Until recently, the $\mathrm{B}_{\mathrm{HW}}$ method was widely used, since it is efficient in detecting and analyzing low soil boron concentration by colorimetry [5]. For alfalfa, Gestring and Soltanpour [6] compared three boron extraction methods (saturation, ammonium bicarbonate-DTPA, and hot water), and found that hot water extraction was the most related to yield [6]. However, cooling time and additional manipulations 
required to compensate water loss by evaporation during extraction make this method slow and imprecise $[7,8]$. Contrarily to Mehlich-3 extraction, hot water extraction is slower and can be done for one element at a time; it is therefore less interesting economically than Mehlich-3 [9] and for soil routine laboratory analyses [10]. The inductively coupled plasma (ICP) spectrometer can analyze multiple soil elements [11] with a same Mehlich-3 solution; this technology allows for the considerable reduction of the costs of soil analyses and an increased efficiency [12]. Shuman et al. [10] proposed to substitute $\mathrm{B}_{\mathrm{HW}}$ by $\mathrm{B}_{\mathrm{M} 3}$ for soil boron diagnostics in six eastern US States. Zbíral and Němec [9] found a significant difference between $\mathrm{B}_{\mathrm{HW}}$ and $\mathrm{B}_{\mathrm{M} 3}$, but the correlation was not high enough to make the substitution. Additionally, Tran et al. [13] proposed a conversion equation $\left(\mathrm{B}_{\mathrm{M} 3}=1.31 \times \mathrm{B}_{\mathrm{HW}}\right)$ for acidic sandy soils and loamy soils in Québec. However, for clay soils with a high exchangeable Ca content and higher $\mathrm{pH}$, the correlation between $\mathrm{B}_{\mathrm{HW}}$ and $\mathrm{B}_{\mathrm{M} 3}$ was almost non-existent. Many diagnostic and recommendation grids based on $\mathrm{B}_{\mathrm{HW}}$ and crop type have been reported in the literature [14-22]. However, to our knowledge, there exists no boron diagnostic and recommendation grid based on $B_{M 3}$. The objectives of this study were: (i) To evaluate $\mathrm{B}_{\mathrm{M} 3}$ from $\mathrm{B}_{\mathrm{HW}}$ for different representative soil types in Québec; (ii) to build, with data from the literature, two agronomical relative yield models, relative yield $(R Y)=$ function $\left(\mathrm{B}_{\mathrm{HW}}\right)$ and $R Y=$ function $\left(\mathrm{B}_{\mathrm{M} 3}\right)$; and (iii) to develop, with yield-boron response curves from the literature, a recommendation relationship based on soil $\mathrm{B}_{\mathrm{M} 3}$, soil $\mathrm{pH}$, boron spreading method, and crop type.

\section{Materials and Methods}

To obtain boron fertilizer recommendations from $\mathrm{B}_{\mathrm{M} 3}$ and other soil chemical properties, the method has been divided into three phases (Figure 1); that is, to develop: (i) Algorithms predicting $\mathrm{B}_{\mathrm{M} 3}$ (database 1), (ii) agronomical response models to both crop fertilizer and soil boron content (database 2), and (iii) algorithms to predict recommended boron rates in case of deficiency (database 3).

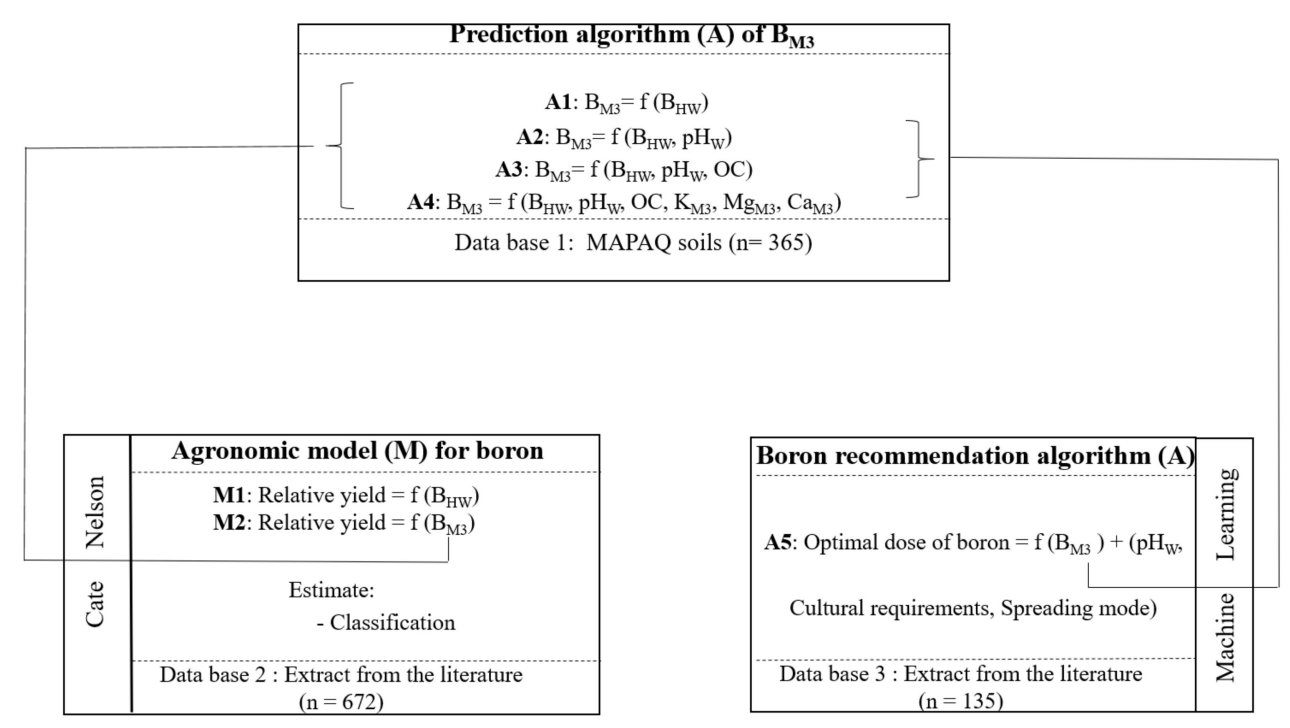

Figure 1. Summary of the different steps in the development of the models for the diagnosis and recommendation of boron in acidic to neutral soils. $\mathrm{B}_{\mathrm{M} 3}$ : Boron Mehlich-3; $\mathrm{B}_{\mathrm{HW}}$ : Boron hot water; $\mathrm{pH}_{\mathrm{W}}$ : $\mathrm{pH}$ water; OC: Organic carbon; $\mathrm{K}_{\mathrm{M} 3}, \mathrm{Mg}_{\mathrm{M} 3}$, and $\mathrm{Ca}_{\mathrm{M} 3}$ are, respectively, Mehlich-3 extracted potassium, magnesium and calcium; MAPAQ: Ministry of Agriculture Fisheries and Food of Quebec.

\subsection{Algorithms for Prediction of Boron Mehlich-3 ( $\left.B_{M 3}\right)$}

To develop these algorithms, we used a database of 365 soil samples (database 1). These samples were taken from about 80 Québec farms dedicated to various productions: Forage crops, field crops, vegetables, and forestry (Table 1 ). 
Table 1. Selected properties of the 365 soil samples in the plough layer $(0-20 \mathrm{~cm})$ (Data base 1).

\begin{tabular}{|c|c|c|c|}
\hline Soil Property & Range & Mean & Standard Deviation \\
\hline $\mathrm{pH}_{\mathrm{W}}$ & $2.30-7.40$ & 6.20 & 0.60 \\
\hline \multicolumn{4}{|c|}{$\mathrm{g} \cdot \mathrm{kg}^{-1}$} \\
\hline Organic carbon & $8-408$ & 45 & 68 \\
\hline Sand & 0-890 & 417 & 234 \\
\hline Silt & $50-600$ & 341 & 145 \\
\hline Clay & $60-850$ & 242 & 159 \\
\hline \multicolumn{4}{|c|}{$\mathrm{mg} \cdot \mathrm{kg}^{-1}$} \\
\hline $\mathrm{B}_{\mathrm{HW}}$ & $0.02-3.68$ & 0.40 & 0.70 \\
\hline $\mathrm{B}_{\mathrm{M} 3}$ & $0.08-12,7$ & 1.00 & 2.30 \\
\hline $\mathrm{Al}_{\mathrm{M} 3}$ & 53-1679 & 966 & 369 \\
\hline $\mathrm{Ca}_{\mathrm{M} 3}$ & 89-17084 & 3856 & 3964 \\
\hline $\mathrm{Mg}_{\mathrm{M} 3}$ & $21-2940$ & 370 & 513 \\
\hline $\mathrm{Fe}_{\mathrm{M} 3}$ & $101-1205$ & 263 & 150 \\
\hline $\mathrm{K}_{\mathrm{M} 3}$ & $29-806$ & 235 & 507 \\
\hline $\mathrm{Cu}_{\mathrm{M} 3}$ & $0.50-30.60$ & 3.00 & 3.30 \\
\hline $\mathrm{Zn}_{\mathrm{M} 3}$ & $0.40-81.40$ & 5.30 & 8.60 \\
\hline
\end{tabular}

$\mathrm{pH}_{\mathrm{W}}$ : $\mathrm{pH}$ water; $\mathrm{B}_{\mathrm{HW}}$ : Boron hot water; $\mathrm{B}_{\mathrm{M} 3}$ : Boron Mehlich-3; $\mathrm{Al}_{\mathrm{M} 3}$ : Aluminium Mehlich-3; $\mathrm{Ca}_{\mathrm{M} 3}$ : Cacium Mehlich-3; $\mathrm{Mg}_{\mathrm{M} 3}$ : Magnesium Mehlich-3; $\mathrm{Fe}_{\mathrm{M} 3}$ : Iron Mehlich-3; $\mathrm{K}_{\mathrm{M} 3}$ : Potassium Mehlich-3; $\mathrm{Cu}_{\mathrm{M} 3}$ : Copper Mehlich-3; $\mathrm{Zn}_{\mathrm{M} 3}$ : Zinc Mehlich-3.

All samples come from the arable layer $(0-20 \mathrm{~cm})$ and have very different soil horizons (Dystric Brunisol, Eutric Brunisol, Melanic Brunisol, Gleysol, Humic Gleysol, Luvic Gleysol, Gray Luvisol, Humic Podzol, Humo-Ferric Podzol, Ferro-Humic Podzol, Regosol and Humic Regosol) [23]. Soil samples were air-dried and sieved with $2 \mathrm{~mm}$ sieves. Soil $\mathrm{pH}$ was determined with a 1:1 soil/solution (vol/vol). Organic carbon (OC) was determined by the Walkley-Black [24] method, and soil texture was determined by the method of Day [25].

Exchangeable bases $\left(\mathrm{K}_{\mathrm{M} 3}, \mathrm{Ca}_{\mathrm{M} 3}, \mathrm{Mg}_{\mathrm{M} 3}\right)$ and trace elements $\left(\mathrm{Al}_{\mathrm{M} 3}, \mathrm{Fe}_{\mathrm{M} 3}, \mathrm{Cu}_{\mathrm{M} 3}, \mathrm{Zn}_{\mathrm{M} 3}, \mathrm{~B}_{\mathrm{M} 3}\right)$ were extracted according to the Mehlich-3 procedure [26] and analyzed with ICP-OES (Thermo Jarrell-Ash model 61-E, Thermo Instrument, Franklin, MA). Boron was extracted from soil using the hot water method of Berger and Truog [5], and it was quantified by colorimetry [27].

The estimation of $\mathrm{B}_{\mathrm{M} 3}$ was performed by supervised learning using the h2o's AutoML [28] algorithm within the $\mathrm{R}$ software (Version 3.0.2) [29]. This algorithm allowed us to predict $\mathrm{B}_{\mathrm{M} 3}$ from $\mathrm{B}_{\mathrm{HW}}$ and a combination of the other predicting variables: $\mathrm{pH}_{\mathrm{W}}, \mathrm{OC}, \mathrm{K}_{\mathrm{M} 3}, \mathrm{Ca}_{\mathrm{M} 3}$, and $\mathrm{Mg}_{\mathrm{M} 3}$. The partial dependence of predicted $\mathrm{B}_{\mathrm{M} 3}$ on each predicting variable was determined with h2o's varimp function, and the correlation was determined between predicted and laboratory measured $\mathrm{B}_{\mathrm{M} 3}$. Additional statistical analyses were done with Excel to determine the means, ranges, and standard deviations of the main soil sample parameters.

\subsection{Boron Agronomical Models}

Database 2 contains a total of 672 values of $\mathrm{B}_{\mathrm{HW}}$ and yield $\left(\mathrm{Y}_{0}\right.$ : Control yield without boron fertilization; $\mathrm{Y}_{\max }$ : Maximal yield of the boron fertilization treatment). These data come from 32 published studies (Table 2) and involve about 40 crop types. To define an agronomic model based on $\mathrm{B}_{\mathrm{M} 3}$, we used the following predictive variables: $\mathrm{pH}_{\mathrm{W}}, \mathrm{OC}, \mathrm{K}_{\text {exchangeable, }} \mathrm{Ca}_{\text {exchangeable }}$ and $\mathrm{Mg}_{\text {exchangeable, }}$ which were all, or partially, available from the literature. This data came under two 
forms: Tables and graphs. Data from tables were taken directly, whereas graphical data were converted to numeric values using the Data Thief software [30].

Table 2. Literature data for the boron agronomic model (Data base 2).

\begin{tabular}{|c|c|c|c|c|c|}
\hline Reference & $n^{*}$ & Cultures & Reference & $n^{*}$ & Cultures \\
\hline Bagchi et al. [31] & 3 & $\mathrm{R}$ & Mahler and Shafii [17] & 224 & $\mathrm{~L}$ \\
\hline Cifu et al. [32] & 1 & Cs & Mahler and Shafii [18] & 268 & $\mathrm{Be}$ \\
\hline Cirak et al. [33] & 1 & $S$ & Malhi et al. [34] & 14 & Can \\
\hline Cutcliffe [35] & 10 & $\mathrm{Gp}$ & Ganie et al. [36] & 3 & $\mathrm{Fb}$ \\
\hline Dunn et al. [37] & 6 & $\mathrm{Ri}$ & Oyewole and Aduayi [38] & 1 & $\mathrm{~T}$ \\
\hline Debnath et al. [39] & 2 & $\mathrm{~W}$ & Rerkasem et al. [40] & 13 & $\mathrm{Pe}, \mathrm{Ri}, \mathrm{S}, \mathrm{Su}, \mathrm{W}, \mathrm{Bb}$ \\
\hline Devi et al. [41] & 2 & $S$ & Sharma et al. [42] & 4 & $\mathrm{Su}$ \\
\hline Dursun et al. [43] & 6 & $\mathrm{~T}, \mathrm{P}, \mathrm{Cu}$ & Sherell [44] & 7 & Rc, Wc, Ac, A \\
\hline Gupta [45] & 6 & W, B & Sherell and Toxopeus [46] & 8 & A \\
\hline Gupta [47] & 20 & A, Rc, Ti & Singh and Singh [48] & 3 & $S$ \\
\hline Gupta and Cutcliffe [15] & 3 & $\mathrm{Br}, \mathrm{Bs}, \mathrm{Cau}$ & Turan et al. [49] & 3 & A \\
\hline Gupta and MacLeod [50] & 4 & $\mathrm{Ti}$ & Valenciano et al. [51] & 3 & $\mathrm{Ch}$ \\
\hline Hussain et al. [52] & 6 & M & Wojcik and Wojcik [53] & 2 & $\mathrm{Pt}$ \\
\hline Davis et al. [54] & 4 & $\mathrm{~T}$ & Wojcik $[55,56]$ & 4 & $\mathrm{Bc}, \mathrm{Hb}$ \\
\hline $\begin{array}{c}\text { Razmjoo and } \\
\text { Henderlong [57] }\end{array}$ & 7 & A & Yu and Bell [58] & 1 & $\mathrm{Ri}$ \\
\hline Lombin [59] & 30 & $\mathrm{Pe}$ & Zhang et al. [60] & 3 & $\mathrm{Ma}$ \\
\hline Total $=672$ & & & & & \\
\hline
\end{tabular}

${ }^{*}$ number of points; $\mathrm{A}=$ Alfalfa; $\mathrm{Ac}=$ Alsike clover; $\mathrm{B}=$ Barley; $\mathrm{Bb}=$ Black beans; $\mathrm{Bc}=$ Black currant; $\mathrm{Be}=\mathrm{Beans}$; $\mathrm{Bl}=$ Blackgram; $\mathrm{Br}=$ Broccoli; $\mathrm{Bs}=$ Brussel sprouts; $\mathrm{Cab}=$ Cabbage; $\mathrm{Can}=$ Canola; $\mathrm{Car}=\mathrm{Carrot} ; \mathrm{Cau}=$ Cauliflower; $\mathrm{Ch}=$ Chickpea; $\mathrm{Cs}=$ Chinese strawberry; $\mathrm{Cu}=$ Cucumber; $\mathrm{Fb}=$ French beans; $\mathrm{Gp}=$ Green peas; $\mathrm{Hb}=$ Highbush blueberry; $\mathrm{L}=$ Lentils; $\mathrm{M}=$ Mustard; $\mathrm{Ma}=$ Mandarin; $\mathrm{P}=$ Pepper; $\mathrm{Pe}=$ Peanuts; $\mathrm{Pt}=$ Pear tree; $\mathrm{R}=\mathrm{Radish} ; \mathrm{Rb}=$ Red bayberry; $\mathrm{Rc}=$ Red clover; $\mathrm{Ri}=$ Rice; $\mathrm{Ru}$ : Rutabaga; $\mathrm{S}=$ Soybean; $\mathrm{Su}=$ Sunflower; $\mathrm{T}=$ Tomato; $\mathrm{Tb}=$ Table beets; $\mathrm{Ti}=$ Timothy; $\mathrm{W}=$ Wheat; $\mathrm{Wc}=$ White clover.

From these 32 studies, we only kept those with $\mathrm{B}_{\mathrm{HW}}$ and those with a soil $\mathrm{pH}_{\mathrm{W}}$ from neutral to acidic. From the data of these studies, the crop nominal yield for the control was expressed as a relative yield with respect to the maximal yield.

$$
R Y(\%)=\frac{Y_{0}\left(\mathrm{~kg} \cdot \mathrm{ha}^{-1}\right)}{Y_{\max }\left(\mathrm{kg} \cdot \mathrm{ha}^{-1}\right)} \times 100
$$

The critical agronomic thresholds of $\mathrm{B}_{\mathrm{HW}}$ or $\mathrm{B}_{\mathrm{M} 3}$ are those for which a significant yield increase will not occur with an additional amount of boron fertilizer [61]. This threshold was determined iteratively according to the Cate-Nelson method [62] using relative yields from all experiments with $\mathrm{B}_{\mathrm{HW}}$ or $\mathrm{B}_{\mathrm{M} 3}$. The Cate-Nelson procedure used identifies critical thresholds with an iterative method that maximizes the sum of squares on the boron axis [63] $\left(\mathrm{B}_{\mathrm{HW}}\right.$ or $\left.\mathrm{B}_{\mathrm{M} 3}\right)$ while minimizing, on the yield axis, the number of points in the error quadrants [64]. Two models $\left(R Y=\right.$ function of $\mathrm{B}_{\mathrm{HW}}$ and $R Y=$ function of $\left.\mathrm{B}_{\mathrm{M} 3}\right)$ were developed using the Cate-Nelson procedure of the rcompanion package [65] with the $\mathrm{R}$ software. For the model $R Y=$ function of $\mathrm{B}_{\mathrm{M} 3}$, an additional step was required because all the predictive variables $\left(\mathrm{B}_{\mathrm{HW}}, \mathrm{pH}_{\mathrm{W}}, \mathrm{OC}, \mathrm{K}_{\text {exchangeable }}, \mathrm{Ca}_{\text {exchangeable }}\right.$ and $\mathrm{Mg}_{\text {exchangeable }}$ ) were not available for all the studies.

We therefore developed four AutoML algorithms: A1, A2, A3 and A4 (Figure 1), corresponding to the following sets of predictive variables, respectively: $\left\{\mathrm{B}_{\mathrm{HW}}\right\},\left\{\mathrm{B}_{\mathrm{HW}}, \mathrm{pH}_{\mathrm{W}}\right\},\left\{\mathrm{B}_{\mathrm{HW}}, \mathrm{pH}_{\mathrm{W}}, \mathrm{OC}\right\},\left\{\mathrm{B}_{\mathrm{HW}}\right.$, $\mathrm{pH}_{\mathrm{W}}, \mathrm{OC}, \mathrm{K}_{\text {exchangeable, }} \mathrm{Ca}_{\text {exchangeable }}$ and $\mathrm{Mg}_{\text {exchangeable }}$. These models were build using results from 365 samples (Database 1) representative of Québec agricultural soils (Table 1). 


\subsection{Boron Recommandation Algorithms}

Database 3 contains 130 curves of yield response to different application rates of boron. This data come from 25 published studies (Table 3). Each of these curves were examined to determine the boron

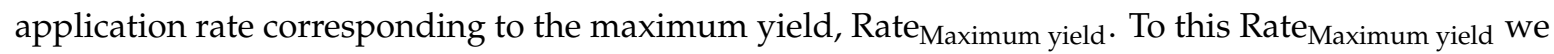
associated (i) the crop type corresponding to one of the two categories of boron requirements (medium, high) as recommended by CRAAQ [4] (Centre de Référence en Agriculture et Agroalimentaire du Québec); (ii) the application type of the boron fertilizer (broadcast, sidedress, field application); and (iii) the soil variables $\mathrm{B}_{\mathrm{HW}}, \mathrm{pH}_{\mathrm{W}}, \mathrm{OC}, \mathrm{K}, \mathrm{Ca}, \mathrm{Mg}$. Prediction of $\mathrm{B}_{\mathrm{M} 3}$ was done using AutoML algorithms $\mathrm{A} 2, \mathrm{~A} 3$ and A4 (Figure 1). The prediction of Rate ${ }_{\text {Maximum yield was performed by algorithm AutoML }}$ A5 using $\mathrm{B}_{\mathrm{M} 3}$, estimated by $\mathrm{A} 2$, $\mathrm{A} 3$ or $\mathrm{A} 4$, crop type, application mode, and soil $\mathrm{pH}_{\mathrm{W}}$.

Table 3. Literature data for the boron recommendation algorithms (Data base 3).

\begin{tabular}{|c|c|c|c|c|c|}
\hline Reference & $n^{*}$ & Cultures & Reference & $n^{*}$ & Cultures \\
\hline Bagchi et al. [31] & 2 & $\mathrm{R}$ & Gupta and Cutcliffe [66] & 2 & $\mathrm{~Tb}, \mathrm{Car}$ \\
\hline Cifu et al. [32] & 1 & $\mathrm{Rb}$ & Haque [67] & 2 & $\mathrm{~T}$ \\
\hline Debnath et al. [39] & 2 & $\mathrm{~W}$ & Hussain et al. [52] & 4 & $\mathrm{M}$ \\
\hline Devi et al. [41] & 2 & $S$ & Mahli et al. [34] & 13 & Can \\
\hline Dursun et al. [43] & 6 & $\mathrm{~T}, \mathrm{P}, \mathrm{Cu}$ & Maurya et al. [68] & 1 & $\mathrm{R}$ \\
\hline Freeborn et al. [69] & 5 & $S$ & Quddus et al. [70] & 3 & $\mathrm{~L}$ \\
\hline Ganie et al. [36] & 3 & $\mathrm{Fb}$ & Rerkasem et al. [40] & 7 & $\mathrm{~S}, \mathrm{Pe}, \mathrm{Bl}, \mathrm{W}$ \\
\hline Gupta [45] & 6 & W, B & Singh and Singh [48] & 3 & $S$ \\
\hline Gupta and Cutcliffe [71] & 20 & $\mathrm{~A}, \mathrm{Rc}, \mathrm{Ti}$ & C. G Sherell [44] & 7 & $\mathrm{~A}, \mathrm{Ac}$ \\
\hline Gupta and Cutcliffe [72] & 3 & $\mathrm{Ru}$ & S.P. Srivastava et al. [73] & 1 & $\mathrm{~L}$ \\
\hline Gupta and Cutcliffe [74] & 16 & $\mathrm{Ru}$ & Turan et al. [49] & 3 & $\mathrm{~A}$ \\
\hline Gupta and Cutcliffe [71] & 16 & $\mathrm{Be}, \mathrm{Cab}$ & & & \\
\hline Total $=130$ & & & & & \\
\hline
\end{tabular}

\section{Results and Discussion}

\subsection{Algorithms for Prediction of Boron Mehlich-3 (BM3}

The results used by our study show a wide range of soil properties (Table 1). Soil texture varies from coarse to fine with a $\mathrm{pH}$ from 2.3 to 7.4 . Soil boron content ranges from 0.02 to $3.68 \mathrm{mg} \mathrm{B} \mathrm{kg}-1$ for $\mathrm{B}_{\mathrm{HW}}$ and from 0.08 to $12.7 \mathrm{mg} \mathrm{B} \mathrm{kg}^{-1}$ for $\mathrm{B}_{\mathrm{M} 3}$. This shows the Mehlich-3 method extracts more boron than hot water, which was also a conclusion of Zbíral and Němec [9] and Shuman et al. [10]. For Québec acidic sandy soils and loamy soils, Tran et al. [13] found that, on average, $B_{\mathrm{M} 3}$ is $31 \%$ more than $\mathrm{B}_{\mathrm{HW}}$. Figure 2 shows simple linear correlations between $\mathrm{B}_{\mathrm{M} 3}$ and $\mathrm{B}_{\mathrm{HW}}$, as well as between predicted and measured $\mathrm{B}_{\mathrm{M} 3}$.

The model of Figure 2a shows a very low correlation between $\mathrm{B}_{\mathrm{HW}}$ and $\mathrm{B}_{\mathrm{M} 3}$, with only $36 \%$ of the $\mathrm{B}_{\mathrm{M} 3}$ variation being explained by the model. Low coefficients of determination $\left(R^{2}=0.29 ; R^{2}=0.45\right)$ between $B_{\mathrm{M} 3}$ and $B_{H W}$ were also observed by Walworth et al. [75]. With such low correlations, such a model cannot be used to transpose $B_{H W}$ values from the literature to $B_{M 3}$ values in order to develop recommendation models or to diagnose soil boron status. Figure $2 b$ shows the prediction quality criteria of $\mathrm{B}_{\mathrm{M} 3}$ using the linear regression from Figure 2a. Compared to a perfect prediction of $\mathrm{B}_{\mathrm{M} 3}$ from $\mathrm{B}_{\mathrm{HW}}$, i.e., a slope (m) of 1.0 and an intercept (a) of 0.0 , we found that $m=0.63$ and that $a=0.36 \mathrm{mg} \mathrm{B} \mathrm{kg}^{-1}$, a value so high that it is close to the average of all 365 samples analyzed $\left(0.40 \mathrm{mg} \mathrm{B} \mathrm{kg}^{-1}\right)$. Such a weak 
model does not allow for a reliable conversion from $\mathrm{B}_{\mathrm{HW}}$ to $\mathrm{B}_{\mathrm{M} 3}$. Therefore, instead of simple linear regression, we used the supervised learning algorithm AutoML (Table 4).

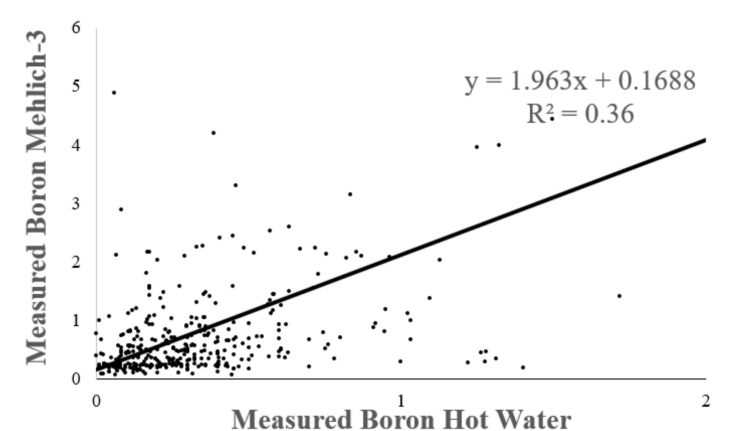

(a)

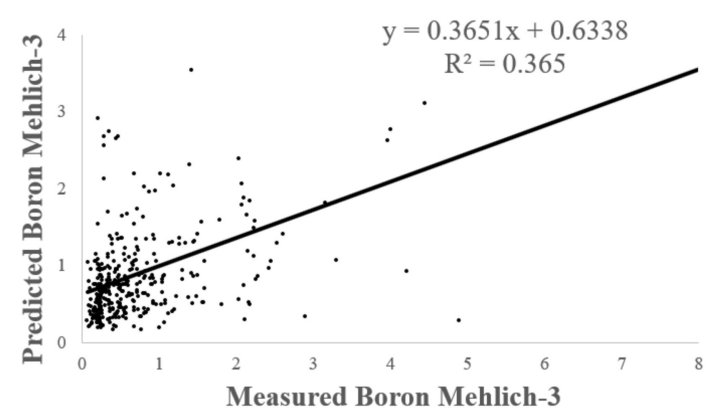

(b)

Figure 2. (a) Linear regression between measured boron extracted by hot water $\left(\mathrm{B}_{\mathrm{HW}}\right)$ and measured boron extracted by the Mehlich-3 solution $\left(\mathrm{B}_{\mathrm{M} 3}\right)$; (b) Linear regression between measured $\mathrm{B}_{\mathrm{M} 3}$ and predicted $\mathrm{B}_{\mathrm{M} 3}$ (by the linear model of Figure 2a).

Table 4. $\mathrm{B}_{\mathrm{M} 3}$ prediction results by four AutoML (Automatic Machine Learnig) algorithms.

\begin{tabular}{cccccc}
\hline & & \multicolumn{4}{c}{ B $_{\text {M3 }}$ predicted vs B $_{\mathbf{M} 3}$ measured } \\
\hline Algorithms & Predictors & $\boldsymbol{m}$ & $\mathbf{1 - m}$ & $\boldsymbol{a}$ & $\boldsymbol{R}^{\mathbf{2}}$ \\
\hline $\mathbf{A 1}$ & $\mathrm{B}_{\mathrm{HW}}$ & 0.35 & 0.65 & 0.38 & 0.63 \\
\hline A2 & $\mathrm{B}_{\mathrm{HW}}, \mathrm{pH}_{\mathrm{W}}$ & 0.63 & 0.37 & 0.23 & 0.85 \\
\hline A3 & $\mathrm{B}_{\mathrm{HW}}, \mathrm{pH}_{\mathrm{W}}, \mathrm{OC}$ & 0.88 & 0.12 & 0.08 & 0.98 \\
\hline A4 & $\begin{array}{c}\mathrm{B}_{\mathrm{HW}}, \mathrm{pH}_{\mathrm{W}}, \mathrm{OC}, \mathrm{K}_{\mathrm{M} 3}, \\
\mathrm{Ca}_{\mathrm{M} 3}, \mathrm{Mg}_{\mathrm{M} 3}\end{array}$ & 0.97 & 0.03 & 0.02 & 0.99
\end{tabular}

$\mathrm{m}$ : Slope; 1-m: Deviation; a: Intercept; $R^{2}$ : Robustness; $\mathrm{B}_{\mathrm{HW}}$ : Boron hot water; $\mathrm{pH}$ : $\mathrm{pH}$ water; OC: Organic carbon; $\mathrm{K}_{\mathrm{M} 3}$ : Potassium Mehlich-3; $\mathrm{Ca}_{\mathrm{M} 3}$ : Calcium Mehlich-3; $\mathrm{Mg}_{\mathrm{M} 3}$ : Magnesium Mehlich-3; $\mathrm{B}_{\mathrm{M} 3}$ : Boron Mehlich-3.

The A1 AutoML algorithm predicted $\mathrm{B}_{\mathrm{M} 3}$ from $\mathrm{B}_{\mathrm{HW}}$ with an $R^{2}$ of 0.63 compared to 0.36 for the linear regression, but intercepts and slopes were similar. Adding predictive variables related to the $\mathrm{B}_{\mathrm{M} 3}$ extraction improved the predictive capacity (Table 4). The algorithm A4 performed better with an $R^{2}$ and a slope close to one, as well as an intercept close to 0 (Figure 3a).

To improve the conversion from $B_{\mathrm{HW}}$ to $\mathrm{B}_{\mathrm{M} 3}$, we included in AutoML A4 five soil parameters that are routinely analyzed by soil laboratories. With all these parameters, a multiple linear regression gives $R^{2}=0.65, a=0.23$ and $m=0.65$ (Figure $3 \mathrm{i}$ ), which results in a deviation of $35 \%(1-\mathrm{m})$ between predicted and measured $\mathrm{B}_{\mathrm{M} 3}$. The improvement in $\mathrm{B}_{\mathrm{M} 3}$ prediction when going from simple regression (Figure $2 \mathrm{~b}$ ) to multiple regression (Figure 3i) and to AutoML shows the potential of using supervised learning algorithm A4. The A4 AutoML algorithm shows only a slight average deviation of 3\%, which is much less than the value of $20 \%$ for inter-laboratory error allowed by the CEAEQ [76] (Centre d'expertise en analyse environnementale du Québec) and an intercept close to the detection limit of $0.01 \mathrm{mg} \mathrm{kg}^{-1}$ [77]. It is to be noted that all slopes, either from regression or supervised learning, are less than 1.0, which implies mainly an under-estimation of $\mathrm{B}_{\mathrm{M} 3}$.

Algorithms A3 and A4 predicted $B_{\mathrm{M} 3}$ with deviations (1-m) less than the $20 \%$ error allowed by CEAEQ [76]. These two algorithms allow for a better prediction of $B_{M 3}$ by using several soil variables from which depend the soil boron status. Recent research used machine learning to obtain reliable predictions [78-80]. Since in Québec routine soil determination includes elements extractible by Mehlich-3, the $\mathrm{pH}$, and soil organic matter [79], algorithm A4 is the most appropriate to convert $B_{\mathrm{HW}}$ to $B_{\mathrm{M} 3}$. The scaled (0-1) importance of the variables used to predict $\mathrm{B}_{\mathrm{M} 3}$ by $\mathrm{A} 4$ is shown in Figure 3b; they are, in order of importance: $\mathrm{Ca}_{\mathrm{M} 3}>\mathrm{pH}_{\mathrm{W}}>\mathrm{B}_{\mathrm{HW}}>\mathrm{Mg}_{\mathrm{M} 3}>\mathrm{OC}>\mathrm{K}_{\mathrm{M} 3}$. The influence 
intervals of each of these predictors are shown in Figure $3 c-h$. Generally, the value of predicted $B_{M 3}$ increased, up to a limit, with the values of the predictors. Contrarily to what was expected, $\mathrm{B}_{\mathrm{HW}}$ is not the most important variable in predicting $\mathrm{B}_{\mathrm{M} 3}$. The two most important variables are $\mathrm{Ca}_{\mathrm{M} 3}$ and $\mathrm{pH}_{\mathrm{W}}$, which is explained by the composition of the Mehlich-3 solution.
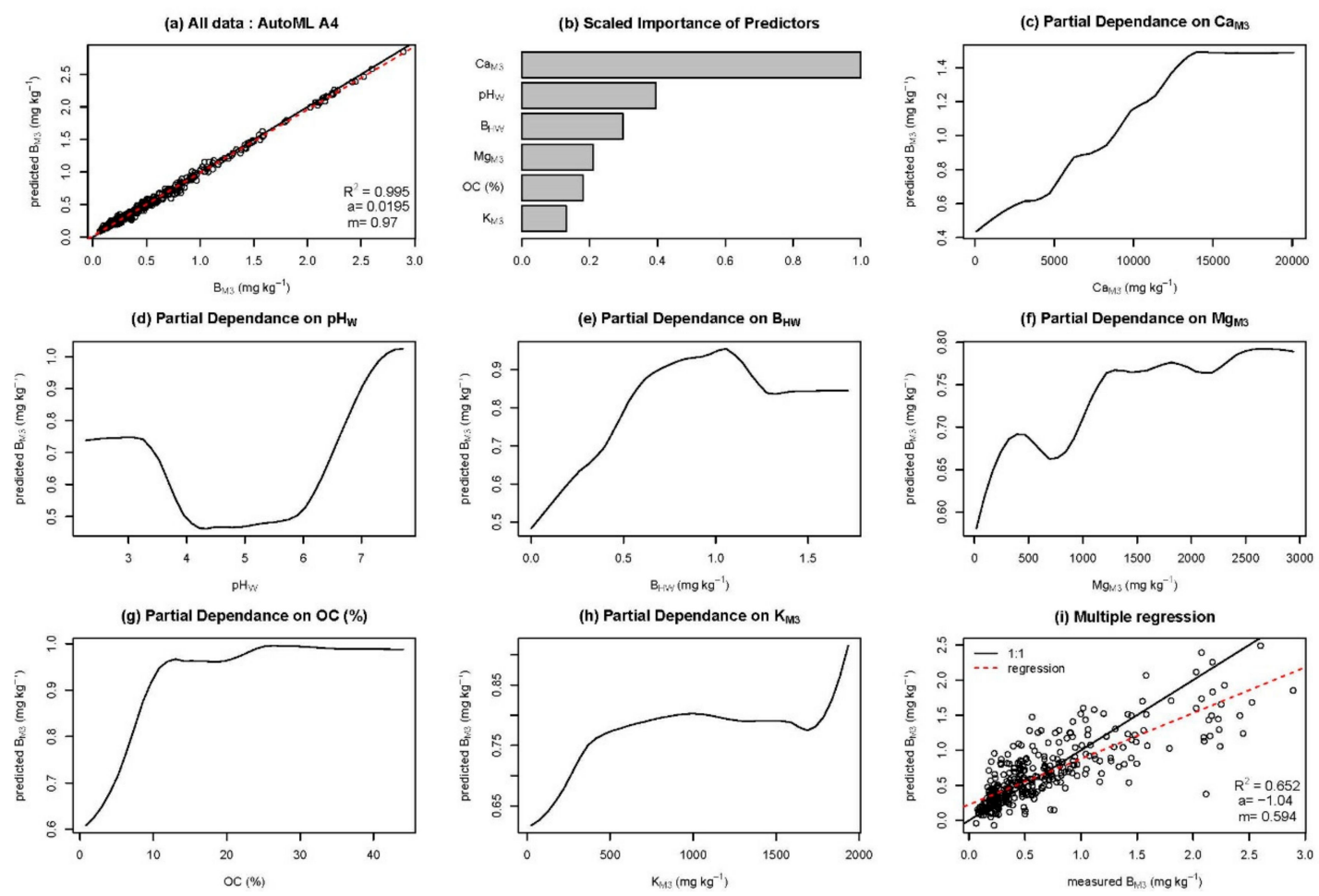

Figure 3. Boron Mehlich-3 $\left(\mathrm{B}_{\mathrm{M} 3}\right)$ prediction and statistical analysis for algorithm AutoML $\mathrm{A} 4(\mathbf{a}-\mathbf{h})$ and for multiple regression (i). (a) Correlation between measured and predicted $\mathrm{B}_{\mathrm{M} 3}$; (b) scaled importance of predictors $\left(\mathrm{Ca}_{\mathrm{M} 3}, \mathrm{pH}_{\mathrm{W}}, \mathrm{Mg}_{\mathrm{M} 3}, \mathrm{~K}_{\mathrm{M} 3}, \mathrm{~B}_{\mathrm{HW}}, \mathrm{OC}\right)$; (c-h) partial dependence on $\mathrm{Ca}_{\mathrm{M} 3}, \mathrm{pH}_{\mathrm{W}} \mathrm{Mg}_{\mathrm{M} 3}, \mathrm{~K}_{\mathrm{M} 3}$, $\mathrm{B}_{\mathrm{HW}}, \mathrm{OC}$, respectively; (i) correlation between measured and predicted $\mathrm{B}_{\mathrm{M} 3}$ by multiple regression.

In comparison with the official method of ammonium acetate $\mathrm{pH} 7$, the Mehlich-3 $\mathrm{pH} 3$ method extracts approximately the same levels of $\mathrm{K}$ and $\mathrm{Mg}$. However, Mehlich-3 extracts more calcium than ammonium acetate, i.e., $17 \%$ [80] or $28 \%$ [26]. This additional extraction could influence the amount of boron moving from the soil to the Mehlich-3 solution. Besides, this is the most plausible reason to explain that $\mathrm{B}_{\mathrm{M} 3}$ is higher than $\mathrm{B}_{\mathrm{HW}}$ [13]. Mehlich [26] included, in his extraction solution, ammonium fluoride $\left(\mathrm{NH}_{4} \mathrm{~F}\right)$ which induces an interaction between soil $\mathrm{pH}$ and that of the solution. Mehlich [26] concluded that soils with a high $\mathrm{pH}$ are at risk of calcium precipitation in the form of $\mathrm{CaF}_{2}$, which makes the Mehlich-3 solution not relevant for alkaline soils $\left(\mathrm{pH}_{W} \geq 7.5\right)$. This is seen in Figure $3 c$, where the $\mathrm{B}_{\mathrm{M} 3}$ is dependent of the exchangeable calcium up to a concentration of about $13,000 \mathrm{mg} \mathrm{Ca} \mathrm{Ca}^{-1}$. A higher $\mathrm{pH}_{\mathrm{W}}$ results in less exchangeable calcium and in an increase of anionic boron in the form of $\mathrm{B}(\mathrm{OH})_{4}{ }^{-}$by the hydrolytic effect [81]. Cancela et al. [82] found that the Mehlich-3 extraction is more reliable for soils with a low calcium content and which are more acidic. In high $\mathrm{pH}$ soils, Tran et al. [13] measured $\mathrm{B}_{\mathrm{M} 3}$ values 2-5.2 more than $\mathrm{B}_{\mathrm{HW}}$; in addition, the correlation between these two variables was almost zero. Moreover, in Figure 3d, we can observe that $B_{M 3}$ is more affected by pH values superior to 6. For organic carbon, $\mathrm{K}_{\mathrm{M} 3}$ and $\mathrm{Mg}_{\mathrm{M} 3}$ (Figure $3 \mathrm{f}-\mathrm{g}$ ) their predictive influences on $\mathrm{B}_{\mathrm{M} 3}$ are within the ranges usually found in Québec mineral soils, i.e., $0 \%-10 \%$ for OC, $0-500 \mathrm{mg} \mathrm{B} \mathrm{kg}^{-1}$ for $\mathrm{K}_{\mathrm{M} 3}$, and $0-1800 \mathrm{mg} \mathrm{B} \mathrm{kg}^{-1}$ for $\mathrm{Mg}_{\mathrm{M} 3}$. 


\subsection{Boron Agronomic Models}

Two models were developed: One based on $\mathrm{B}_{\mathrm{HW}}$ (Figure 4) and another based on predicted $\mathrm{B}_{\mathrm{M} 3}$ (Figure 5). The Cate-Nelson procedure applied to these two models allowed for the definition of two critical thresholds: 0.23 and $0.58 \mathrm{mg} \mathrm{B}_{\mathrm{HW} \mathrm{kg}}{ }^{-1}$ (Figure $4 \mathrm{c}$ ) and 0.65 and $1.03 \mathrm{mg} \mathrm{B}_{\mathrm{M} 3} \mathrm{~kg}^{-1}$ (Figure 5c). These thresholds correspond to high points of the curve between the sum of squares and the variable concerned [62]. These critical values allowed us to partition soil boron into three fertility classes for diagnostics: Low, medium and high. For $\mathrm{B}_{\mathrm{HW}}$, these three classes correspond, respectively, to $0-0.23,0.23-0.58$, and $0.58-3.70 \mathrm{mg} \mathrm{B}_{\mathrm{HW}} \mathrm{kg}^{-1}$, whereas for $\mathrm{B}_{\mathrm{M} 3}$ they are $0-0.65,0.65-1.03$, and 1.03-12.70 $\mathrm{mg} \mathrm{B}_{\mathrm{M} 3} \mathrm{~kg}^{-1}$. The high probabilities of economical response for crops to boron fertilizers are in the true positive quadrants (TP) of low boron contents, i.e., less than $0.23 \mathrm{mg} \mathrm{B}_{\mathrm{HW}} \mathrm{kg}^{-1}$ or less than $0.65 \mathrm{mg} \mathrm{B}_{\mathrm{M} 3} \mathrm{~kg}^{-1}$, which correspond to relative yield from 20 to $85 \%$ and from 20 to $95 \%$, respectively. The high limits of $85 \%$ and $95 \%$ for critical relative yield were obtained by minimizing the number of points in the error quadrants: false negative(FN) + false positive (FP) of Figures $4 \mathrm{~b}$ and $5 \mathrm{~b}$ for $\mathrm{B}_{\mathrm{HW}}$ and $\mathrm{B}_{\mathrm{M} 3}$, respectively. Contrarily, stable yields are observed in the true negative quadrants (TN) corresponding to low probabilities that yields respond to boron fertilization. In these TN quadrants, relative yield values reach a stability [64] ranging from $85 \%$ to $100 \%$ for $\mathrm{B}_{\mathrm{HW}}$ and from $95 \%$ to $100 \%$ for $\mathrm{B}_{\mathrm{M} 3}$ (Figures $4 \mathrm{a}$ and $5 \mathrm{a}$ ). Error quadrants (FP) correspond to high relative yields despite pertaining to a low boron fertility class, whereas FN quadrants correspond to low relative yield while being in a high boron fertility class. For Figures 4 and 5, we obtained a robustness $R^{2}$ of 82.6 and $69.1 \%$, respectively, corresponding to the probability to make a correct diagnosis for soil boron. For both cases, model robustness was high. These $R^{2}$ values are defined as the ratio the number of points in quadrants TP and $\mathrm{TN}$ to the total number of points. The specificity $\mathrm{TN} /(\mathrm{TN}+\mathrm{FP})$ represents the probability to make the correct decision (do not fertilize) with respect to all observations with a yield stability, i.e., a relative yield $>85 \%$ or $>95 \%$, respectively, for the models of Figures 4 and 5 . These specificities were $83.8 \%$ and $65.1 \%$ for the $\mathrm{B}_{\mathrm{HW}}$ model (Figure 4 ) and the $\mathrm{B}_{\mathrm{M} 3}$ model (Figure 5), respectively.

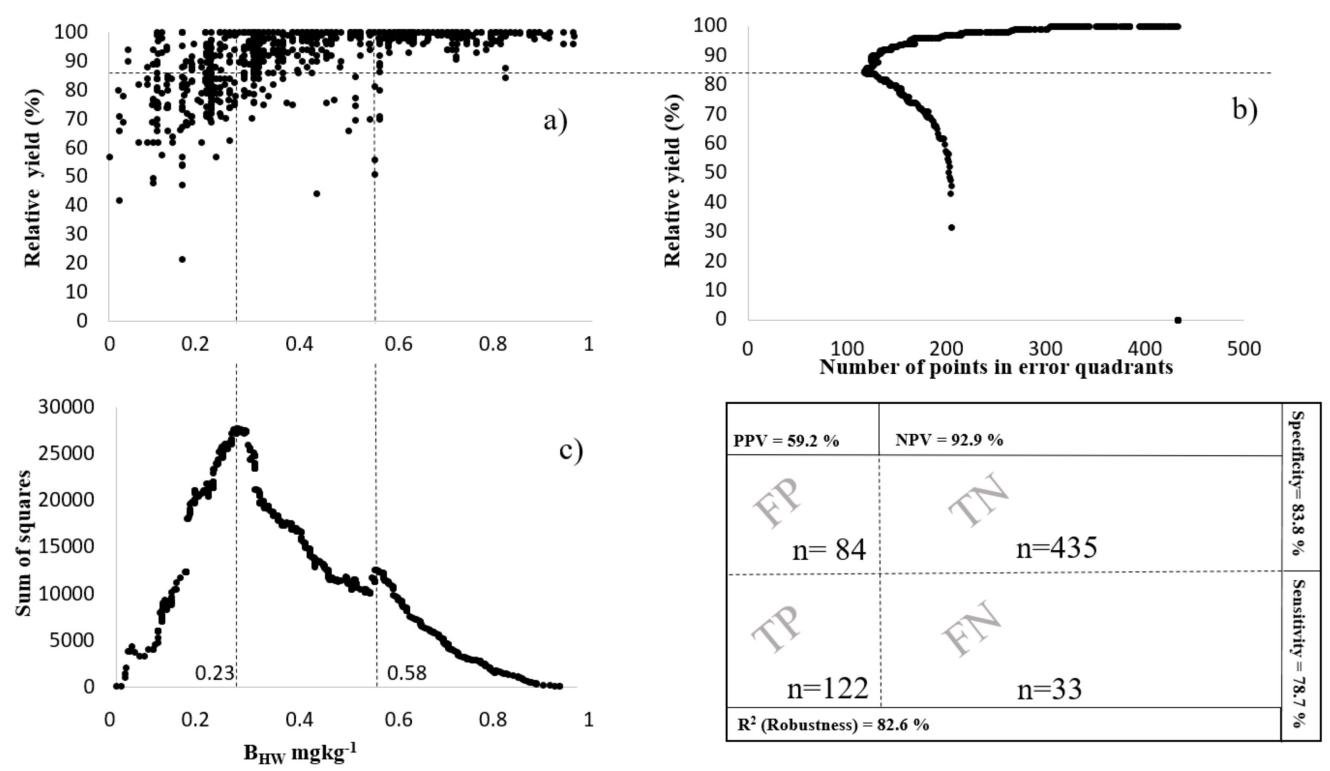

Figure 4. Construction of the diagnostic and statistical model of the Cate-Nelson classification for hot water boron showing the (a) Cate-Nelson graph for the critical thresholds identified; (b) number of points outside the model for determination of the critical relative yield $(R Y)$; (c) sum of squares for determination al of the critical $\mathrm{B}_{\mathrm{HW}}$; and summary table (lower right)n: Number of points in the different quadrants; Performance indicators of the partition model. $R^{2}$, accuracy; NPV, negative predictive value; PPV, positive predictive value. 


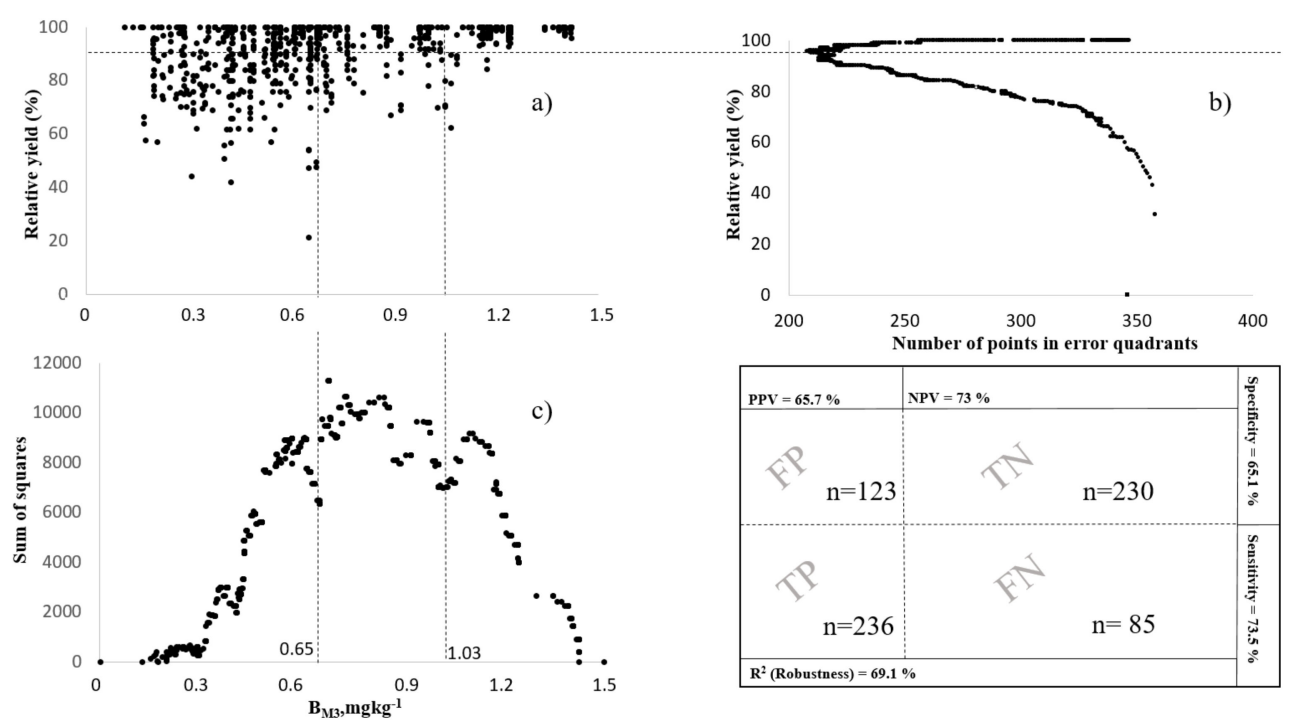

Figure 5. Construction of the diagnostic and statistical model of Cate-Nelson classification for boron Mehlich-3 showing the (a) Cate-Nelson graph for the critical thresholds identified; (b) number of points outside the model for the determination of the critical relative yield $(R Y)$; (c) sum of squares for determination of the critical $\mathrm{B}_{\mathrm{M} 3}$; and and summary table (lower right) $n$ : Number of points in the different quadrants; Performance indicators of the partition model. $R^{2}$, accuracy; NPV, negative predictive value; PPV, positive predictive value.

These values of $83.8 \%$ and $65.1 \%$ represent the probability that high relative yield be associated to soil with a boron content higher to the agronomical critical threshold of $0.23 \mathrm{mg} \mathrm{kg}^{-1}$ for $\mathrm{B}_{\mathrm{HW}}$ and $0.65 \mathrm{mg} \mathrm{kg}^{-1}$ for $\mathrm{B}_{\mathrm{M} 3}$. The sensitivity $[\mathrm{TP} /(\mathrm{TP}+\mathrm{FN})]$ represents the probability to make a good decision to fertilize with boron with respect to all observations with less relative yields, i.e., a relative yield $<85 \%$ for the models in Figure 4 or $<95 \%$ for the models in Figure 5 . These sensitivities were $78.7 \%$ for the $\mathrm{B}_{\mathrm{HW}}$ model and $73.5 \%$ for the $\mathrm{B}_{\mathrm{M} 3}$ model. In these cases, the sensitivity is the probability that lower yields occur for soils with a boron content less than the critical agronomical threshold of $0.23 \mathrm{mg} \mathrm{kg}-1$ for $\mathrm{B}_{\mathrm{HW}}$ and $0.65 \mathrm{mg} \mathrm{kg}^{-1}$ for $\mathrm{B}_{\mathrm{M} 3}$. Positive predictive values (PPV) $[\mathrm{TP} /(\mathrm{TP}+\mathrm{FP})]$ are the probability of a positive response of yield to boron fertilization when soil boron content is less than the critical agronomic threshold of $0.23 \mathrm{mg} \mathrm{kg}^{-1}$ for $\mathrm{B}_{\mathrm{HW}}$ and $0.65 \mathrm{mg} \mathrm{kg}^{-1}$ for $\mathrm{B}_{\mathrm{M} 3}$. These PPVs are $59.2 \%$ for the $\mathrm{B}_{\mathrm{HW}}$ model (Figure 4 ) and $65.7 \%$ for the $\mathrm{B}_{\mathrm{M} 3}$ model (Figure 5).

The negative predictive values (NPV) $[\mathrm{TN} /(\mathrm{TN}+\mathrm{FN})]$ are the probability that crops do not respond to boron fertilization when the soil boron content is more than the critical agronomical threshold. These NPVs are $92.9 \%$ for the $\mathrm{B}_{\mathrm{HW}}$ model (Figure 4) and $73.0 \%$ for the $\mathrm{B}_{\mathrm{M} 3}$ model (Figure 5). As can be seen from Figures 4 and 5, the distribution patterns of the points are similar, with small statistical differences from the Cate-Nelson partitioning. The $\mathrm{B}_{\mathrm{HW}}$ agronomical model shows better statistics (robustness, specificity, sensitivity, PPV, NPV) than the $\mathrm{B}_{\mathrm{M} 3}$ agronomical model. The better performance of the $\mathrm{B}_{\mathrm{HW}}$ model is explained by the fact that it is developed from measured $\mathrm{B}_{\mathrm{HW}}$ values, whereas the $B_{M 3}$ model is based on the results of four algorithms with a predictive power ranging from $65 \%$ to $99 \%$. Moreover, the critical relative yield value of $95 \%$ for the $\mathrm{B}_{\mathrm{M} 3}$ model is more limiting than the value of $85 \%$ for the $\mathrm{B}_{\mathrm{HW}}$ model; this causes the $\mathrm{B}_{\mathrm{M} 3}$ model having more points in the error quadrants.

Since the $\mathrm{B}_{\mathrm{M} 3}$ method extracts more boron from the soil, the critical agronomical thresholds are higher for $\mathrm{B}_{\mathrm{M} 3}$ than for $\mathrm{B}_{\mathrm{HW}}$. Besides, Datta et al. [83] found, for a same culture and for identical experimental conditions, different critical thresholds with four boron extraction methods. The two critical thresholds that we found $\left(0.65\right.$ and $\left.1.03 \mathrm{mg} \mathrm{B}_{\mathrm{M} 3} \mathrm{~kg}^{-1}\right)$ are located in the median part of the interval [0.1 to $2.0 \mathrm{mg} \mathrm{B}_{\mathrm{HW} \mathrm{kg}}{ }^{-1}$ ] [84], below which soil boron fertility is classified as low to medium [85]. 


\subsection{Boron Recommendation Model}

Usually, a recommendation model for a given element is based solely on the soil content of that element, which implies that yield depends on that element only and that any other fertility indicators or fertilization practices do not have any influence. However, Simard et al. [86] proposed considering both $\mathrm{pH}_{\mathrm{W}}$ and $\mathrm{B}_{\mathrm{M} 3}$ for boron recommendations. Additionally, Gupta and Cutcliffe [74] showed the effect of boron spreading type on crop yield. It is also known that boron requirements vary from crop to crop [4]. Therefore, the AutoML A5 algorithm, combining all these factors to predict the boron dose, gave good results, as shown in Figure 6.
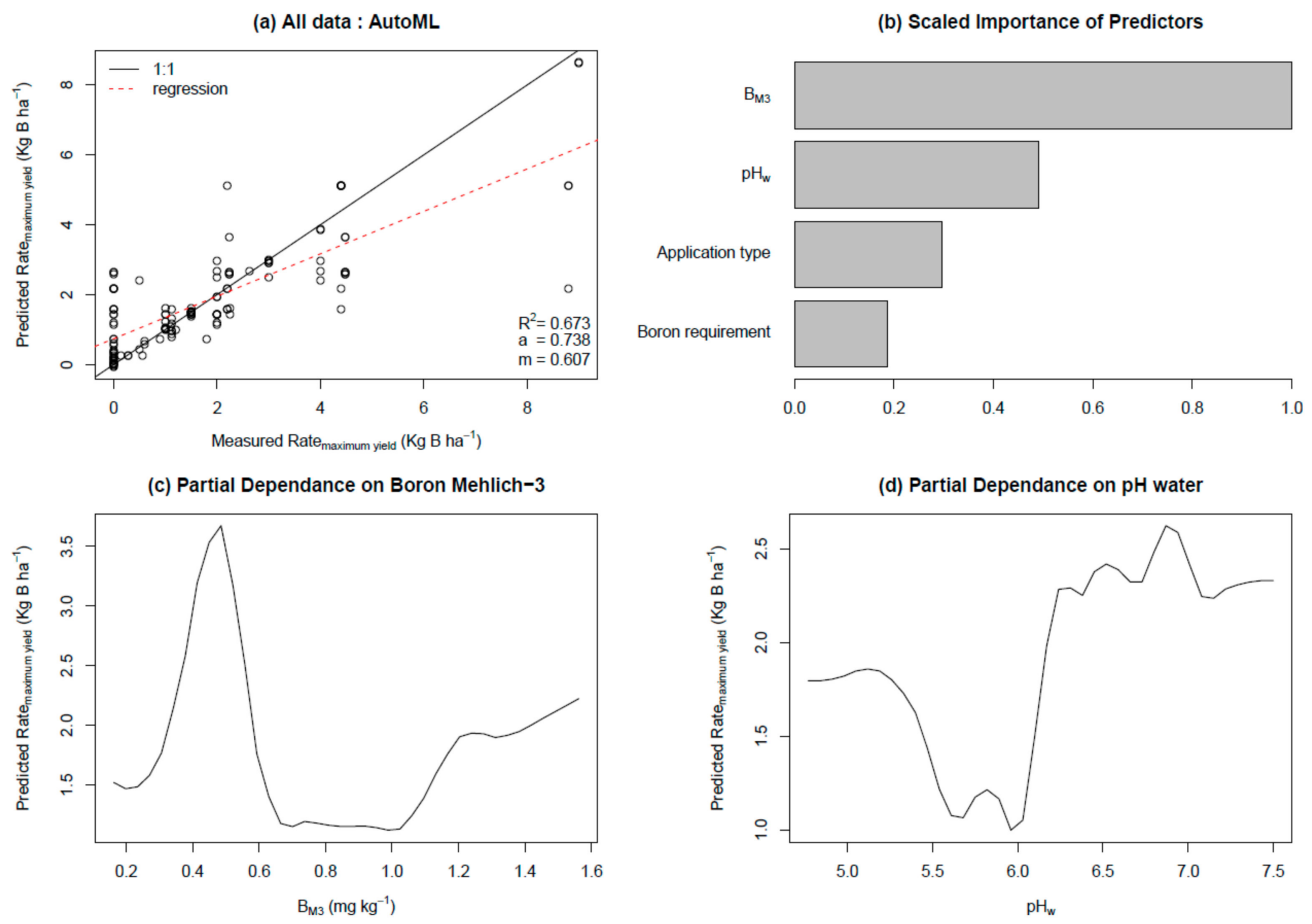

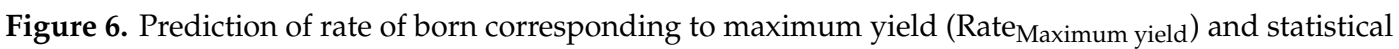
analysis. (a) Correlation between measured and predicted Rate Maximum yield; (b) scaled importance of predictors $\left(\mathrm{B}_{\mathrm{M} 3}, \mathrm{pH}_{\mathrm{W}}\right.$, application type, boron requirement); (c) partial dependence on $\mathrm{B}_{\mathrm{M} 3} ;(\mathbf{d})$ partial dependence on $\mathrm{pH}_{W}$.

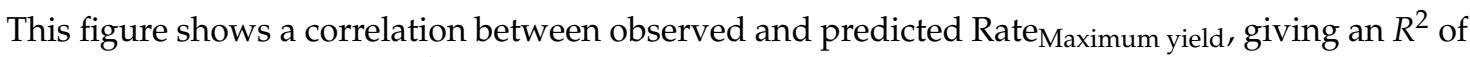
0.63 , an intercept of $0.6 \mathrm{~kg} \mathrm{~B} \mathrm{ha}^{-1}$, and a slope of 0.7 . Therefore, $63 \%$ of the Rate Maximum yield variance is explained by the model. Usually, recommendation models presented in the literature have very low $R^{2}$ values. For a same soil analysis, these models present so much variation that researchers use averages or mathematical expectations to propose recommended rates [87]. The A5 algorithm underestimates Rate Maximum yield, as it shows a mean deviation of $30 \%$ between observed and predicted

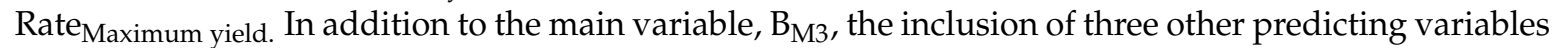
( $\mathrm{pH}_{\mathrm{W}}$, application type and crop boron requirements) in the $\mathrm{A} 5$ algorithm significantly improves the boron rate prediction. This improvement is explained by the interaction between $B_{M 3}$ and the three other variables. As shown in Figure $6 \mathrm{~b}, \mathrm{pH}_{\mathrm{W}}$ is the second most important predicting variable after $\mathrm{B}_{\mathrm{M} 3}$. In Figure $6 \mathrm{c}$, the least influencing interval of $\mathrm{B}_{\mathrm{M} 3}$ is located between 0.65 and $1.03 \mathrm{mg} \mathrm{B}_{\mathrm{M} 3} \mathrm{~kg}^{-1}$, which coincides with the critical agronomical values of the model of Figure $5 \mathrm{a}$. This interval is between the region of boron deficiency $\left(\mathrm{B}_{\mathrm{M} 3}<0.65 \mathrm{mg} \mathrm{kg}^{-1}\right)$ and that of boron sufficiency $\left(\mathrm{B}_{\mathrm{M} 3}>1.03 \mathrm{mg} \mathrm{kg}^{-1}\right)$. It is within this intermediary interval that we find the most estimation error on the boron recommended dose. Besides, in the proposed agronomical model (Figure 5), the points in the error quadrant FN are mostly concentrated in this interval. Therefore, the boron recommendation is relatively less reliable 
within that interval than outside of it. Figure $6 \mathrm{~d}$ shows that for a $\mathrm{pH}_{\mathrm{W}}$ above 6.0 , the required boron amount to reach maximum yield is increased.

This figure also shows that for a range of $3 \mathrm{pH}_{\mathrm{W}}$ units (from 4.5 to 7.5 ), the interval of recommended application rate is from 1 to $2.5 \mathrm{~kg} \mathrm{ha}^{-1}$. This is in concordance with findings of Peterson and Newman [88], who recommend a boron rate of 2.5 higher for a soil $\mathrm{of} \mathrm{pH}_{\mathrm{W}}$ of 7.4 compared to another with a $\mathrm{pH}_{\mathrm{W}}$ of 4.7. These observations show the fixation of boron added to the soil increase considerably when the soil acidity is neutralized, which implies the application of higher boron rates. While predicting variables $\mathrm{B}_{\mathrm{M} 3}$ and $\mathrm{pH}_{\mathrm{W}}$ are numerical, the two others (spreading type and crop boron requirement) are categorical; however, they also have an effect on boron recommended rates. The 130 crop response curves analyzed (Database 3) show that Rate Maximum yield decreases for the following order of application type: Broadcast $>$ sidedress $>$ foliar application. Such a difference due to the application method is explained by the fact that fertilizer losses are greater for broadcasting than for sidedress and for foliar application [89]. With the proposed A5 multi-variable model, boron fertilizer applications can be done with more precision. The precision of this A5 model could be further increased as more data become available.

\section{Summary and Conclusions}

In this study, we used three databases to develop a multi-variable system for soil boron diagnostics and recommendation. Database 1 is composed of 365 soil samples representative of the various Québec agricultural regions. This database was used to develop an AutoML algorithm (A4) which successfully converts $\mathrm{B}_{\mathrm{HW}}$ to $\mathrm{B}_{\mathrm{M} 3}$ using five covariates $\left(\mathrm{pH}_{\mathrm{W}}, \mathrm{OC}, \mathrm{Ca}_{\mathrm{M} 3}, \mathrm{Mg}_{\mathrm{M} 3}\right.$ and $\mathrm{K}_{\mathrm{M} 3}$ ). This $\mathrm{A} 4$ algorithm allows for a robust prediction of $99 \%$ (with only a slight $3 \%$ average deviation) and an intercept so small that it is in the same order of magnitude as the detection limit of $0.01 \mathrm{mg} \mathrm{kg}^{-1}$ of $\mathrm{B}_{\mathrm{M} 3}$. Database 2 is composed of 672 observations coming completely from published literature and was used to develop two agronomical models, one for $\mathrm{B}_{\mathrm{HW}}$ and one for $\mathrm{B}_{\mathrm{M} 3}$. These two models showed critical thresholds defining the intervals of medium deficiency, that is 0.23 and $0.58 \mathrm{mg} \mathrm{kg}^{-1}$ for $\mathrm{B}_{\mathrm{HW}}$ and 0.65 and $1.03 \mathrm{mg} \mathrm{kg}^{-1}$ for $\mathrm{B}_{\mathrm{M} 3}$. These two intervals discriminate soils with a risk of boron deficiency from those with high potential of boron sufficiency. Database 3 include 130 crop yield response to various boron rates; all data were extracted from the literature. These response curves allowed us to

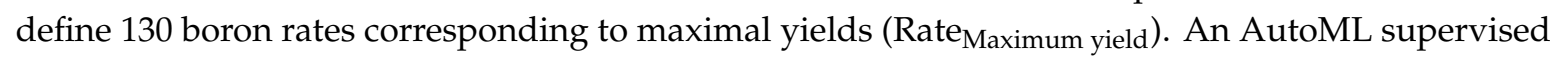
learning algorithm, $\mathrm{A} 5$, allowed us to relate $\mathrm{Rate}_{\text {Maximum yield }}$ to $\mathrm{B}_{\mathrm{M} 3}, \mathrm{pH}_{\mathrm{W}}$, fertilizer application type, and boron crop requirement category. With an $R^{2}$ of $63 \%$, the performance of algorithm A5 is much greater than those of other recommendation models based solely on soil reserves. Results from this study show the superiority of supervised learning compared to traditional prediction methods, despite the heterogeneity of sources and data. It therefore becomes possible to include boron in the common extractant of Mehlich-3 to diagnose and recommend boron fertilization, especially because this method is well suited to the neutral to acidic soils in Québec.

Author Contributions: D.R., K.L. and G.J. planned and designed the research; D.R. carried out the experiments; D.R. and K.L. wrote the manuscript; J.C. was involved in structuring the research.

Funding: This research did not receive any external funding.

Acknowledgments: We are grateful to Ministry of Agriculture Fisheries and Food of Quebec (MAPAQ) for the access to their soil database.

Conflicts of Interest: The authors declare that there is no conflict of interest.

\section{References}

1. Du, C.; Zhou, J. Evaluation of soil fertility using infrared spectroscopy: A review. Environ. Chem. Lett. 2009, 7, 97-113. [CrossRef]

2. Gupta, U.C.; Wu, K.; Liang, S. Micronutrients in soils, crops, and livestock. Earth Sci. Front. 2009, 15, 110-125. [CrossRef] 
3. Lindsay, W.L.; Cox, F.R. Micronutrient soil testing for the tropics. Fertil. Res. 1985, 7, 169-199. [CrossRef]

4. Parent, L.E.; Gagné, G. CRAAQ Guide de Référence en Fertilisation, 2nd ed.; Centre de Référence en Agriculture et Agroalimentaire du Québec: Québec, QC, Canada, 2010; p. 473.

5. Berger, K.C.; Truog, E. Boron Determination in Soils and Plants Using the Quinalizarin Reaction. Ind. Eng. Chem. Anal. Ed. 1939, 11, 540-545. [CrossRef]

6. Soltanpour, W.D.; Gestring, P.N. Evaluation of the ammonium bicarbonate-DTPA soil test for assessing boron availability to alfalfa. Soil Sci. Soc. Am. J. 1984, 48, 96-100.

7. Offiah, O.; Axley, J.H. Improvement of boron soil test. Commun. Soil Sci. Plant Anal. 1988, 19, 1527-1542. [CrossRef]

8. Wei, Y.; Zarcinas, B.A. An improved procedure for the extraction of plant available soil boron. In Boron in Soils and Plants; Springer: Dordrecht, The Netherlands, 1997; pp. 77-81.

9. Zbíral, J.; Němec, P. Comparison of some soil extractants for determination of boron. Commun. Soil Sci. Plant Anal. 2009, 40, 96-105. [CrossRef]

10. Shuman, L.M.; Bandel, V.A.; Donohue, S.J.; Isaac, R.A.; Lippert, R.M.; Sims, J.T.; Tucker, M.R. Comparison of mehlich-1 and mehlich-3 extractable soil boron with hot-water extractable boron. Commun. Soil Sci. Plant Anal. 1992, 23, 1-14. [CrossRef]

11. Şimşek, A.; Korkmaz, D.; Velioğlu, Y.S.; Ataman, O.Y. Determination of boron in hazelnut (Corylus avellana L.) varieties by inductively coupled plasma optical emission spectrometry and spectrophotometry. Food Chem. 2003, 83, 293-296. [CrossRef]

12. Redd, S.A.; Shiffler, A.K.; Jolley, V.D.; Webb, B.L.; Haby, V.A.; Shiffler, A.K.; Jolley, V.D.; Webb, B.L.; Haby, V.A. Mehlich 3 Extraction of Boron in Boron Treated Soils as Compared to Other Extractants. Commun. Soil Sci. Plant Anal. 2008, 39, 1245-1259. [CrossRef]

13. Tran, T.S.; Giroux, M.; Audesse, P.; Guilbault, J. Importance des elements mineurs en agriculture. Agrosol 1995, 8, 12-22.

14. Gupta, U.C.; Cutcliffe, J.A. Boron nutrition of broccoli, brussel sprouts, and cauliflower grown on Prince Edward Island soils. Can. J. Soil Sci. 1973, 53, 275-279. [CrossRef]

15. Gupta, U.C.; Cutcliffe, J.A. Boron deficiency in cole crops under field and greenhouse conditions. Commun. Soil Sci. Plant Anal. 1975, 6, 181-188. [CrossRef]

16. Rashid, A.; Rafique, E.; Bughio, N. Diagnosing boron deficiency in rapeseed and mustard by plant analysis and soil testing. Commun. Soil Sci. Plant Anal. 1994, 25, 2883-2897. [CrossRef]

17. Mahler, R.L.; Shafii, B. Relationship between soil-test boron and lentil yields in the inland Pacific Northwest. Commun. Soil Sci. Plant Anal. 2007, 38, 1193-1202. [CrossRef]

18. Mahler, R.L.; Shafii, B. Relationship between soil test boron and pea yields in the inland Pacific Northwest. Commun. Soil Sci. Plant Anal. 2009, 40, 2603-2615. [CrossRef]

19. Loué, A. Micronutrients in Agriculture [Oligo-Éléments en Agriculture]; SCPA-NATHAN: Antibes, France, 1993.

20. Mohib, R.; Naz, M.; Muhammad, S.; Hamid, A.; Bibi, F. Effect of boron on the flowering and fruiting of tomato. Sarhad J. Agric. 2012, 28, 37-40.

21. Moniruzzaman, M.; Rahman, S.M.L.; Kibria, M.G.; Rahman, M.A.; Hossain, M. Effect of boron and nitrogen on yield and hollowstem of broccoli. J. Soil Nat. 2007, 1, 24-29.

22. Nyomora, A.M.S.; Brown, P.H.; Krueger, B. Rate and time of boron application increase almond productivity and tissue boron concentration. HortScience 1999, 34, 242-245. [CrossRef]

23. Agriculture Canada Expert Committee on Soil Survey. The Canadian System of Soil Classification, 2nd ed.; Agriculture Canada Publishing: Ottawa, ON, Canada, 1987.

24. Nelson, D.W.; Sommers, L.E. Total carbon, organic carbon, and organic matter. In Methods of Soil Analysis, 2nd ed.; Page, A.L., Ed.; American Society of Agronomy: Madison, WI, USA, 1982.

25. Day, P.R. Particle fractionation and particle size analysis. In Methods of Soil Analysis; Black, C.A., Ed.; American Society of Agronomy: Madison, WI, USA, 1965; Volume 1.

26. Mehlich, A. Mehlich 3 soil test extractant: A modification of Mehlich 2 extractant. Commun. Soil Sci. Plant Anal. 1984, 15, 1409-1416. [CrossRef]

27. John, M.K.; Chuah, H.H.; Neufeid, H.J. Application of improved azomethine-H-method to the determination of boron in soil and plants. Anal. Lett. 1975, 8, 559-568. [CrossRef] 
28. LeDell, E.; Gill, N.; Aiello, S.; Fu, A.; Candel, A.; Click, C.; Kraljevic, T.; Nykodym, T.; Aboyoun, P.; Kurka, M.; et al. Package 'h2o': R Interface for 'H2O'. 2019. Available online: https://github.com/h2oai/h2o-3 (accessed on 20 July 2019).

29. R Development Core Team. R: A Language and Environment for Statistical Computing; Foundation for Statistical Computing: Vienna, Austria, 2016.

30. Tummers, B. Data Thief III Manual V 1.1. 2006, p. 52. Available online: https://datathief.org/ (accessed on 20 July 2019).

31. Bagchi, D.K.; Banerjee, A.; Bhattacharya, B. Effect of nitrogen, boron and molybdenum on yield of root and leaf protein of radish (Raphanus sativus). Indian J. Agric. Sci. 1988, 58, 224-226.

32. Cifu, M.; Zhihong, C.; Peikuen, J.; Guomo, Z.; XianGui, L.; Qiufang, X. Effects of application of boron on growth, yields, and quality of red bayberry. J. Plant Nutr. 2007, 30, 1047-1058. [CrossRef]

33. Cirak, C.; Odabas, M.S.; Kevseroglu, K.; Karaca, E.; Gulumser, A. Response of soybean (Glycine max) to soil and foliar applied boron at different rates. Indian J. Agric. Sci. 2006, 76, 603-606.

34. Malhi, S.S.; Raza, M.; Schoenau, J.J.; Mermut, A.R.; Kutcher, R.; Johnston, A.M.; Gill, K.S. Feasibility of boron fertilization for yield, seed quality and B uptake of canola in northeastern Saskatchewan. Can. J. Soil Sci. 2002, 83, 99-108. [CrossRef]

35. Cutcliffe, J.A. Effects of boron, molybdenum and lime on yield and leaf tissue nutrient concentration of green peas. Can. J. Plant Sci. 1986, 66, 971-976. [CrossRef]

36. Ganie, M.A.; Farida Akhter, M.A.B.; Najar, G.R. Growth, yield and quality of french bean (PHASEOLUS VULGARIS L.) as influenced by sulphur and boron application on inceptisols of Kashmir. Bioscan 2014, 9, 513-518.

37. Dunn, D.; Stevens, G.; Kending, A. Boron fertilization of rice with soil and foliar applications. Crop Manag. 2005, 1, 1-10.

38. Oyewole, O.I.; Aduayi, E.A. Evaluation of the growth and quality of the "ife plum" tomato as affected by boron and calcium fertilization. J. Plant Nutr. 1992, 15, 199-209. [CrossRef]

39. Debnath, M.R.; Jahiruddin, M.; Rahman, M.M.; Haque, M.A. Determining optimum rate of boron application for higher yield of wheat in Old Brahmaputra Floodplain soil. J. Bangladesh Agric. Univ. 2011, 9, $205-210$. [CrossRef]

40. Rerkasem, B.; Netsangtip, R.; Bell, R.W.; Loneragan, J.F.; Hiranburana, N. Comparative species responses to boron on a Typic Tropaqualf in Northern Thailand. Plant Soil 1988, 106, 15-21. [CrossRef]

41. Devi, K.N.; Singh, L.N.K.; Sumarjit Singh, M.; Basanta Singh, S.; Khamba Singh, K. Influence of Sulphur and Boron Fertilization on Yield, Quality, Nutrient Uptake and Economics of Soybean (Glycine max) under Upland Conditions. J. Agric. Sci. 2012, 4, 1-10. [CrossRef]

42. Sharma, K.R.; Srivastava, P.C.; Ghosh, D.; Gangwar, M.S. Effect of boron and farmyard manure application on growth, yields, and boron nutrition of sunflower. J. Plant Nutr. 1999, 22, 633-640. [CrossRef]

43. Dursun, A.; Turan, M.; Ekinci, M.; Gunes, A.; Esringü, A.; Yildirim, E. Effects of boron fertilizer on tomato, pepper, and cucumber yields and chemical composition. Commun. Soil Sci. Plant Anal. 2010, 41, 1576-1593. [CrossRef]

44. Sherrell, C.G. Boron deficiency and response in white and red clovers and lucerne. New Zeal. J. Agric. Res. 1983, 26, 197-203. [CrossRef]

45. Gupta, U.C. Effects of boron and limestone on cereal yields and on B and N concentrations of plant tissue. Pant Soil 1977, 47, 283-287. [CrossRef]

46. Sherrell, C.G.; Toxopeus, M.R.J. Effects of boron applications on yield and boron concentration of lucerne (medicago sativa 1.) grown on yellow-brown pumice soils. New Zeal. J. Exp. Agric. 1978, 6, 145-150. [CrossRef]

47. Gupta, U.C. Boron nutrition of alfalfa, red clover, and timothy grown on podzol soils of eastern Canada. Soil Sci. 1984, 137, 16-22. [CrossRef]

48. Singh, A.K.; Singh, S. Response of soybean to phosphorus and boron fertilization in acidic upland soil of Nagaland. J. Indian Soc. Soil Sci. 2012, 60, 3-6.

49. Turan, M.; Ketterings, Q.M.; Gunes, A.; Ataoglu, N.; Esringü, A.; Bilgili, A.V.; Huang, M.Y. Boron fertilization of Mediteranean aridisols improves lucerne (Medicago Sativa L.) yields and quality. Soil Plant Sci. 2009, 60, 427-436. 
50. Gupta, U.C.; Macleod, J.A. Boron nutrition and growth of timothy as affected by soil pH. Commun. Soil Sci. Plant Anal. 1973, 4, 389-395. [CrossRef]

51. Valenciano, J.B.; Boto, J.A.; Marcelo, V. Response of chickpea (Cicer arietinum L.) yield to zinc, boron and molybdenum application under pot conditions. Span. J. Agric. Res. 2010, 8, 797-807. [CrossRef]

52. Hussain, M.J.; Sarker, M.M.R.; Sarker, M.H.; Ali, M.; Salim, M.M.R. Effect of different levels of boron on the yield and yield attributes of mustard in surma-kushiara flood plain soil (AEZ 20). J. Soil Nat. 2008, 2, 6-9.

53. Wojcik, P.; Wojcik, M. Effects of boron fertilization on 'Conference' pear tree vigor, nutrition, and fruit yield and storability. Plant Soil 2003, 256, 413-421. [CrossRef]

54. Davis, J.M.; Sanders, D.C.; Nelson, P.V.; Lengnick, L.; Sperry, W.J. Boron improves growth, yield, quality, and nutrient content of tomato. J. Am. Soc. Hortic. Sci. 2003, 128, 441-446. [CrossRef]

55. Wojcik, P. Response of black currant to boron fertilization. J. Plant Nutr. 2005, 28, 63-72. [CrossRef]

56. Wojcik, P. Response of 'bluecrop' highbush blueberry to boron fertilization. J. Plant Nutr. 2005, 28, 1897-1906. [CrossRef]

57. Razmjoo, K.; Henderlong, P.R. Effect of potassium, sulfur, boron, and molybdenum fertilization on alfalfa production and herbage macronutrient contents. J. Plant Nutr. 1997, 20, 1681-1696. [CrossRef]

58. Yu, X.; Bell, P.F. Boron and lime effects on yield and deficiency symptoms of rice grown in greenhouse on acid typic glossaqualf. J. Plant Nutr. 2002, 25, 2591-2602. [CrossRef]

59. Lombin, G. Evaluation of the Micronutrient Fertility of Nigeria's Semi-Arid Savannah Soils: Boron and Molybdenum. Soil Sci. Plant Nutr. 1985, 31, 13-25. [CrossRef]

60. Zhang, Y.; Hu, C.; Tan, Q.; Nie, Z.; Zheng, C.; Gui, H.; Sun, X.; Zhao, X. Soil application of boron and zinc influence fruit yield and quality of Satsuma mandarin in acidic soils. Agron. J. 2015, 107, 1-8. [CrossRef]

61. Zamuner, E.; Lloveras, J.; Echeverría, H. Can Agronomic Phosphorus Recommendations for Potato be Environmentally Sustainable? Better Crop. Plant Food 2017, 101, 20-22.

62. Nelson, L.A.; Anderson, R.L. Soil testing: Correlating and interpreting the analytical results. In Partitioning of Soil Test-Crop Response Probability; Stelly, M., Ed.; ASA Spec. Publ.: Madison, WI, USA, 1984; pp. $19-38$.

63. Cate, R.B.; Nelson, L.A. A Simple Statistical Procedure for Partitioning Soil Test Correlation Data Into Two Classes. Soil Sci. Soc. Am. J. 1971, 35, 658-660. [CrossRef]

64. Beegle, D. Interpretation of soil testing results. In Recommended Soil Testing Procedures for the Northeastern United States; Sims, J.T., Wolf, A.M., Eds.; Agricultural Experiment Stations: Newark, DE, USA, 1995; pp. 111-118.

65. Mangiafico, S. Package R ‘Rcompanion' Version 2.2.1. 2019. Available online: http://rcompanion.org/ (accessed on 20 July 2019).

66. Gupta, U.C.; Cutcliffe, J.A. Boron nutrition of carrots and table beets grown in a boron deficient soil. Commun. Soil Sci. Plant Anal. 1985, 16, 509-516. [CrossRef]

67. Haque, M.E.; Paul, A.K.; Sarker, J.R. Effect of Nitrogen and Boron on the Growth and Yield of Tomato (Lycopersicon esculentum M.). Int. J. Bio. Ressour. Stress Manag. 2011, 2, 277-282.

68. Maurya, A.N.; Rai, K.N.; Lal, S. Effects of boron and nitrogen fertilizers on radish (RAPHANUS SATIVUS). Exp. Agric. 1977, 13, 301-303. [CrossRef]

69. Freeborn, J.R.; Holshouser, D.L.; Alley, M.M.; Powell, N.L.; Orcutt, D.M. Soybean yield response to reproductive stage soil-applied nitrogen and foliar-applied boron. Agron. J. 2001, 93, 1200-1209. [CrossRef]

70. Quddus, M.A.; Nasser, H.M.; Hossain, M.A.; Abul Hossain, M. Effect of zinc and boron on yield and yield contributing characters of lentil in low ganges river floodplain soil at madaripur, Bangladesh. Bangladesh J. Agric. Res. 2014, 39, 591-603. [CrossRef]

71. Gupta, U.C.; Cutcliffe, J.A. Effects of applied and residual boron on the nutrition of cabbage and fields beans. Can. J. Soil Sci. 1984, 64, 571-576. [CrossRef]

72. Gupta, U.C.; Cutcliffe, J.A. Determination of optimum levels of boron in rutabaga leaf tissue and soil. Soil Sci. 1971, 111, 382-385. [CrossRef]

73. Srivastava, S.P.; Bhandari, T.M.S.; Yadav, C.R.; Joshi, M.; Erskine, W. Boron deficiency in lentil: Yield loss and geographic distribution in a germplasm collection. Plant Soil 2000, 219, 147-151. [CrossRef]

74. Gupta, U.C.; Cutcliffe, J.A. Effects of methods of boron application on leaf tissue concentration of boron and control of brown-heart in rutabaga. Can. J. Plant Sci. 1978, 58, 63-68. [CrossRef]

75. Walworth, J.L.; Panciera, M.T.; Gavlak, R.G. Mehlich 3 extractant for determination of available B, Cu, Fe, Mn, and Zn in cryic Alaskan soils. Can. J. Soil Sci. 1992, 72, 517-526. [CrossRef] 
76. Centre d'Expertise en Analyse Environnementale du Québec. Critères de Variation Relatifs; Ministère du Développement durable, de l'Environnement et des Parcs du Québec: Québec, QC, Canada, 2015; Volume 24.

77. Centre d'Expertise en Analyse Environnementale du Québec. Détermination des métaux, des oligoéléments, $d u$ phosphore et $d u$ soufre par les méthodes d'extraction Mehlich-III, extraction du bore à l'eau chaude et dosage par spectrométrie d'émission au plasma d'argon; Ministère de l'Environnement du Québec: Québec, QC, Canada, 2003.

78. Brungard, C.W.; Boettinger, J.L.; Duniway, M.C.; Wills, S.A.; Edwards, T.C. Machine learning for predicting soil classes in three semi-arid landscapes. Geoderma 2015, 239, 68-83. [CrossRef]

79. Morellos, A.; Pantazi, X.E.; Moshou, D.; Alexandridis, T.; Whetton, R.; Tziotzios, G.; Wiebensohn, J.; Bill, R.; Mouazen, A.M. Machine learning based prediction of soil total nitrogen, organic carbon and moisture content by using VIS-NIR spectroscopy. Biosyst. Eng. 2016, 152, 104-116. [CrossRef]

80. Pantazi, X.E.; Moshou, D.; Alexandridis, T.; Whetton, R.L.; Mouazen, A.M. Wheat yield prediction using machine learning and advanced sensing techniques. Comput. Electron. Agric. 2016, 121, 57-65. [CrossRef]

81. Kaplan, D.I.; Adriano, D.C.; Mills, G.L.; Sajwan, K.S.; Burkman, W.G. Determination of boron in soils containing inorganic and organic boron sources. Soil Sci. Soc. Am. J. 1990, 54, 708-714. [CrossRef]

82. Cancela, R.C.; De Abreu, C.A.; Paz-González, A. DTPA and Mehlich-3 micronutrient extractability in natural soils. Commun. Soil Sci. Plant Anal. 2002, 33, 2879-2893. [CrossRef]

83. Datta, S.P.; Bhadoria, P.B.S.; Kar, S. Availability of extractable boron in some acid soils, West Bengal, India. Commun. Soil Sci. Plant Anal. 1998, 29, 2285-2306. [CrossRef]

84. Sims, J.T.; Johnson, G.V. Micronutrients soil tests. In Micronutrients in Agriculture; Mortvedt, J.J., Ed.; Soil Science Society of America: Madison, WI, USA, 1991; pp. 427-476.

85. Korndörfer, G.H.; Snyder, G.H.; Ulloa, M.; Powell, G.; Datnoff, L.E. Calibration of soil and plant silicon analysis for rice production. J. Plant Nutr. 2001, 24, 1071-1084. [CrossRef]

86. Simard, R.R.; Charron, G.; Pageau, D. Field calibration of boron soil tests for barley. Commun. Soil Sci. Plant Anal. 1996, 27, 1631-1646. [CrossRef]

87. Khiari, L.; Parent, L.E.; Pellerin, A.; Alimi, A.R.A.; Tremblay, C.; Simard, R.R.; Fortin, J. An agri-environmental phosphorus saturation index for acid coarse-textured soils. J. Environ. Qual. 2000, 29, 1561-1567. [CrossRef]

88. Peterson, L.A.; Newman, R.C. Influence of soil pH on the availability of added boron1. Soil Sci. Soc. Am. J. 1976, 40, 280-282. [CrossRef]

89. Gupta, U.C. Essential elements-micronutrients. In Hanbook of Plant Nutrition; Barker, A.V., Pilbeam, D.J., Eds.; CRC Press: Boca Raton, FL, USA, 2007; pp. 241-277. 